\title{
Isolation and Spasmolytic Evaluation of New Alkaloids from Dichrostachys cinerea (L.) Wight et Arn. (Fabaceae)
}

\author{
Amenan Geneviève N'guessan-Irié ${ }^{1,2}, J_{o ̈ l}$ Dade $^{1}$, Pierre Champy ${ }^{1,3}$, N'doua Gisèle Siransy-Kouakou $^{2}$, \\ Véronique Leblais ${ }^{3,4}$ \\ ${ }^{1}$ Chimie des Substances Naturelles, CNRS UMR 8076 BioCIS, Châtenay-Malabry, France; ${ }^{2}$ Laboratoire de Pharmacologie et Physiologie, \\ UFR Sciences Pharmaceutiques et Biologiques, Université Félix Houphouët-Boigny, Abidjan, République de Côte d'Ivoire; ${ }^{3}$ Faculté \\ de Pharmacie, Université Paris-Sud 11, Châtenay-Malabry, France; ${ }^{4}$ INSERM UMR-S 769, Châtenay-Malabry, France. \\ Email: jemigrace@gmail.com
}

Received September $23^{\text {rd }}, 2013$; revised October $28^{\text {th }}, 2013$; accepted November $15^{\text {th }}, 2013$

Copyright (C) 2013 Amenan Geneviève N'guessan-Irié et al. This is an open access article distributed under the Creative Commons Attribution License, which permits unrestricted use, distribution, and reproduction in any medium, provided the original work is properly cited.

\begin{abstract}
Dichrostachys cinerea (L.) Wight et Arn. (Fabaceae) root bark is used in Ivorian Traditional Medicine to treat asthma, which is a respiratory disorder characterized by inflammation and the restriction of tracheal muscles obstructing the air circulation. The tracheal relaxant effect of a crude aqueous-alcoholic extract of the plant root bark was previously shown. For the present study, alkaloids were isolated from the same extract and investigated ex vivo in $\mathrm{C} 57 \mathrm{Bl} / 6 \mathrm{j}$ mice isolated trachea contracted with carbachol $1 \mu \mathrm{M}$, in comparison with a reference bronchodilatator, i.e. salbutamol. Two extraction procedures allowed isolating 2 Alkaloids that monodimensional and bi-dimensional nuclear magnetic resonance (NMR) and mass specters allowed identifying a pyrolidine structure type nucleus with a long bi-hydroxyled alkyl chain. Alkaloid 1, carrier of a sugar, is a glycoside of Alkaloid 2. Both alkaloids induced similar spasmolytic effects, but Alkaloid 1 was more effective than Alkaloid 2 at $9 \times 10^{-6} \mathrm{M}(p<0.01), 3 \times 10^{-5} \mathrm{M}$, and $9 \times 10^{-5} \mathrm{M}(p<0.001)$. Salbutamol induced its spasmolytic effect in a different way, and its maximal effect $\mathrm{E}_{\max }$ (less than $30 \%$ ) was obtained at $9 \times 10^{-6} \mathrm{M}$, while $\mathrm{E}_{\max }$ of both alkaloids $(100 \%)$ was obtained at $3 \times 10^{-4} \mathrm{M}$.
\end{abstract}

Keywords: Alkaloids Isolated; Plant; Spasmolytic; Asthma

\section{Introduction}

Dichrostachys cinerea (L.) Wight et Arn. (Fabaceae), among others numerous plants, is commonly used, alone or in association with other plants, in African Traditional Medicine. The ethnobotanic inquiries state that the roots of this plant are astringent and used in rheumatism, urinary calculi and renal troubles [1]; in Togo, the root decoction is administered by oral route in abscesses [2]. In Ivory Coast, whereas the root decoction is used as mouthwash in case of tooth decays by people of the North, people of the South use it to treat asthma [3]. As asthma is a respiratory disorder which is essentially characterized by the restriction of tracheal muscles obstructing the air circulation [4], the tracheal relaxant effect of a crude aqueous-alcoholic extract of the plant root bark was previously shown [5]. Besides, bisnordihydrotoxiferine, a tertiary indole alkaloid isolated from the root of Strychnos divaricans was shown to antagonize ace- tylcholine-induced contractions in rat uterus and in guineapig ileum [6]; other alkaloids were also shown to have spasmolytic effects on guinea-pig isolated trachea contracted by carbachol, histamine, or $\mathrm{KCl}$ [7]. For the present study, alkaloids were isolated from the root bark extract and investigated ex vivo in mice isolated trachea in comparison with a reference bronchodilatator, i.e. salbutamol.

\section{Materials and Methods}

\subsection{Plant Material}

The roots of $D$. cinerea were collected in September 2009 in the South-East of Ivory Coast in bushes near Grand-Bassam. The plant was authenticated by Professor Aké-Assi Laurent, a taxonomist at the Centre National de Floristique (Ivory Coast), in comparison with identified specimens and vouchers were deposited there. The barks 
were removed from the roots, washed in distilled water, air-dried at air-conditioning temperature $\left(18^{\circ} \mathrm{C}\right)$ for two weeks, and pulverized. Dehydration yield was $55.2 \%$.

\subsection{Extraction Procedure}

The research for alkaloids in the crude extract was made by reactions of characterization in tube with the reactive of Valsen-Mayer, then on Thin Layer Chromatography plates revealed by the reactive of Dragendorff.
After that, two ways were used to isolate alkaloids from the crude aqueous-alcoholic extract of the plant root bark: direct division and division after acidification then alkalinisation (Figure 1).

\subsection{Pharmacological Tests}

Alkaloids isolated from $D$. cinerea root bark were performed on mice isolated trachea pre-contracted with carbachol $1 \mu \mathrm{M}$ in the aim to evaluate their spasmolytic effect.

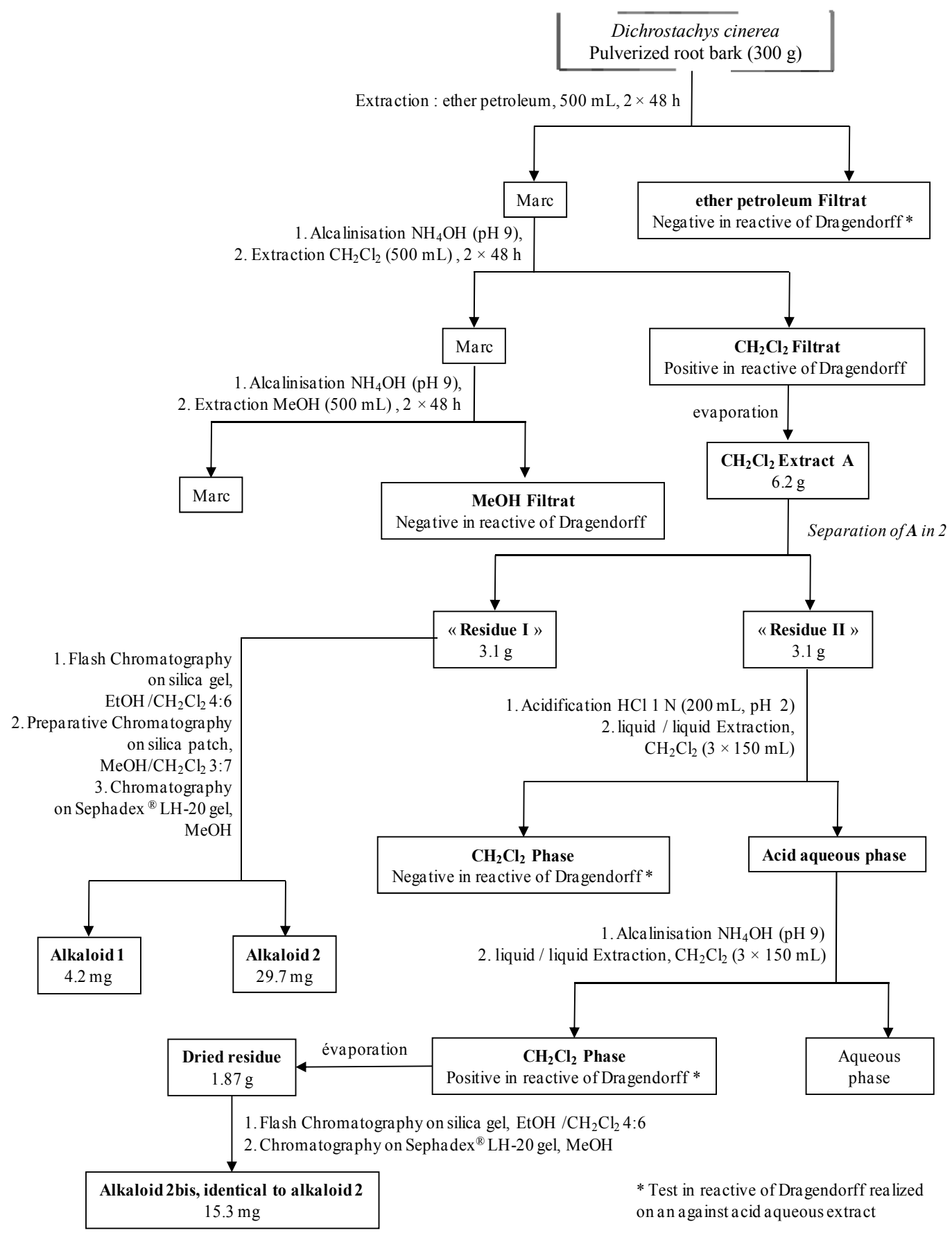

Figure 1. Pure alkaloids extraction scheme. 


\subsubsection{Preparation of Solutions}

Alkaloids isolated, as well as the reference product (salbutamol), were extemporaneously dissolved and serially diluted in distilled water $\left(3 \times 10^{-5}, 3 \times 10^{-4}, 3 \times 10^{-3}\right.$ and $\left.3 \times 10^{-2} \mathrm{M}\right)$.

\subsubsection{Chemicals}

Salbutamol and carbachol were purchased from SigmaAldrich Chemicals, France; all salts $\left(\mathrm{NaCl}, \mathrm{KCl}, \mathrm{KH}_{2} \mathrm{PO}_{4}\right.$, $\mathrm{MgSO}_{4}, \mathrm{CaCl}_{2}$ and $\mathrm{NaHCO}_{3}$ ) and d-glucose from Prolabo.

\subsubsection{Animals}

All experiments were performed in accordance with the European Community guiding principles in the care and use of animals $\left(86 / 609 /\right.$ CEE, CE Off. J. no. L358, $18^{\text {th }}$ December 1986), the European Ethics Committee (CREEA Ile-de-France Sud) guidelines, and the French Decree no. 87 - 848 (J Off République Française, 20 October 1987: pp 12245-12248). Experiments were performed on male C57BL/6J mice at 7 - 8 weeks of age (25 - 30 g; Elevage Janvier, Le Genest Saint Isle, France).

\subsubsection{Preparation of Trachea Rings and ex Vivo Procedure}

Mice were anesthetized with pentobarbital $(60 \mathrm{mg} / \mathrm{kg}$ i.p.). The upper respiratory tract and associated alimentary tissue were rapidly excised and placed in ice-cold Krebs bicarbonate solution containing: $\mathrm{NaCl} 117 \mathrm{mM}$, $\mathrm{KCl} 5.36 \mathrm{mM}, \mathrm{NaHCO}_{3} 25 \mathrm{mM}, \mathrm{KH}_{2} \mathrm{PO}_{4} 1.03 \mathrm{mM}$, $\mathrm{MgSO}_{4} 0.57 \mathrm{mM}, \mathrm{CaCl}_{2} 2.5 \mathrm{mM}$, D-glucose $11.1 \mathrm{mM}$. The tracheas were dissected free from surrounding tissue and cut into 2-mm length segments, which were suspended isometrically between 2 stainless steel hooks in organ chambers containing $5 \mathrm{~mL}$ Krebs bicarbonate solution at $37^{\circ} \mathrm{C}$ and continuously gassed with a mixture of $95 \%$ oxygen and $5 \%$ carbon dioxide. Isometric tension was recorded in real time by a force-displacement transducer connected to the PowerLab ${ }^{\circledR}$ data acquisition system controlled by the Chart $^{\circledR}$ version 5 data analysis software (AD Instruments, Bella Vista, Australia). The rings were stretched in a stepwise manner to a resting value of $0.6 \mathrm{~g}$ for at least 1 hour. Tracheal rings were then challenged with $10^{-5} \mathrm{M}$ carbachol (Sigma-Aldrich Chemicals, France) to evaluate their functional integrity. After a 45-minutes washout period, tracheal preparations were precontracted with a submaximal concentration of carbachol $\left(10^{-6} \mathrm{M}\right)$. After stabilization of the contraction, cumulative additions of the different products and of distilled water as control vehicle were performed.

\subsubsection{Data Analysis and Statistics}

Chemically, isolated components' structure has been analyzed using monodimensional NMR $\left({ }^{1} \mathrm{H},{ }^{13} \mathrm{C}\right)$, bi-dimen- sional NMR (DEPT, COSY, HMBC, HSQC, NOESY), and mass (ESI, APCI, high resolution) specters.

Biologically, the relaxant response of the tracheal rings was expressed as percentage of the precontractile tone induced by carbachol. The effect of vehicle (distilled water) was systematically subtracted from the effect of the products.

Results are expressed as mean \pm standard errors of the mean (S.E.M) of 6 experiments. $E_{\max }$ is the maximal relaxation obtained and $\mathrm{CE}_{\mathrm{X}}$ is the concentration of product which induces $\mathrm{X} \%$ relaxation. Data were analyzed with Sigmaplot ${ }^{\circledR}$ software by an unpaired Student's t-test or by one way analysis of variance (ANOVA) followed by Holm-Sidak or Bonferroni-test, with criterion set for statistical significance at $\mathrm{p}<0.05$.

\section{Results and Discussion}

The analysis of the root bark extract highlighted the presence of an alkaloid fraction (tests in reactive of Valsen-Mayer and in reactive of Dragendorff were positive) which purification allowed obtaining $49.2 \mathrm{mg}$ of total alkaloids, purification yield being $0.0164 \%$.

The division allowed isolating 2 majority pure products. Their monodimensional and bi-dimensional nuclear magnetic resonance specters (NMR) allowed identifying a new structure in alkaloids' serial: pyrolidin with a bi-hydroxyled long alkyl chain (Figures 2 and 4) confirmed by mass spectrometry. These compounds are called Alkaloid 1 (4.2 mg; y $=0.0014 \%)$, Alkaloid 2 $(29.7 \mathrm{mg} ; \mathrm{y}=0.0099 \%)$ and Alkaloid $2 \mathrm{bis}(15.3 \mathrm{mg} ; \mathrm{y}=$ $0.0051 \%$ ), alkaloids 2 and 2 bis being identical compounds isolated by two different ways.

These data allow proposing the fact that Alkaloid 1, carrier of a sugar, is a glycoside of Alkaloid 2 (baptized JEMIGRACINE by our care).

Not aromatic, these isolated alkaloids probably arise from lysine metabolism [8].

Both alkaloids 1 and 2 induced almost similar regular spasmolytic effects $\left(E_{\max }\right.$ value in Table 1). However, Alkaloid 1 was more effective than Alkaloid 2 at $9 \times$ $10^{-6} \mathrm{M}(p<0.01), 3 \times 10^{-5} \mathrm{M}$ and $9 \times 10^{-5} \mathrm{M}(p<0.001)$ just like indicated on Figure 3 and in Table 1 (lowest $\mathrm{EC}_{25}$ and $\mathrm{EC}_{50}$ for alkaloid 1), probably because of the sugar component which could make the cell entry easier,

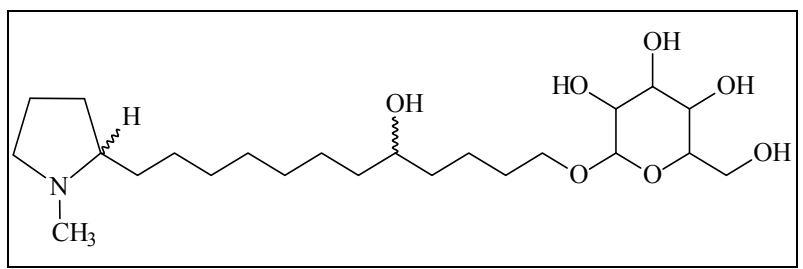

Figure 2. Structure of alkaloid 1 = [5-hydroxy-12-(1-methylpyrrolidin-2-yl)dodecyl hexopyranoside]. 
Table 1. $\mathbf{E}_{\max }, \mathrm{EC}_{50}$ and $\mathrm{EC}_{25}$ of isolated alkaloids and salbutamol.

\begin{tabular}{lccc}
\hline & $\mathrm{E}_{\max }(\%)$ & $\mathrm{EC}_{25}\left(\times 10^{-5} \mathrm{~mol} / \mathrm{L}\right)$ & $\mathrm{EC}_{50}\left(\times 10^{-5} \mathrm{~mol} / \mathrm{L}\right)$ \\
\hline Alkaloid 1 & $104.5 \pm 0.9$ & $2.22 \pm 0.25$ & $5.22 \pm 0.77$ \\
Alkaloid 2 & $104.2 \pm 1.8$ & $4.32 \pm 0.41$ & $9.27 \pm 0.8$ \\
Salbutamol & $28.1 \pm 3.2$ & $6.87 \pm 0.22$ & n.d \\
\hline
\end{tabular}

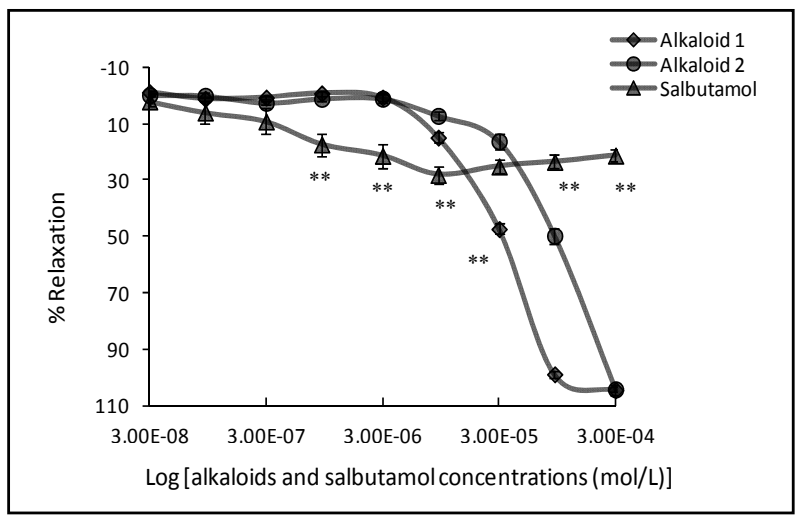

Figure 3. Relaxant effects of alkaloids isolated from $D$. cinerea and salbutamol; **: statistically significance $\mathrm{p} \leq 0.01$.

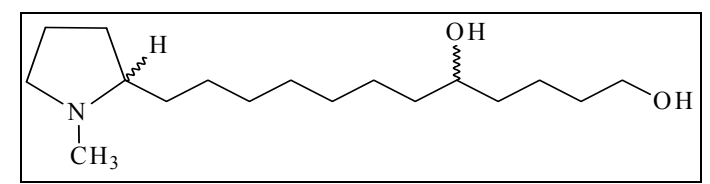

Figure 4. Structure of alkaloid 2 = [12-(1-méthylpyrrolidin2-yl) dodecane-1,5-diol].

like the numerous hydroxyls of aminosides (amino-glycosides) that modulate the penetration of the antibiotic in the bacterium and so play on the specter of action by widening it. $\mathrm{E}_{\max }$ for salbutamol (less than $30 \%$ ) was obtained at $9 \times 10^{-6} \mathrm{M}$ while the one of both alkaloids, corresponding to a total deletion of contractions, was obtained at $3 \times 10^{-4} \mathrm{M}$.

Differences between Alkaloids' effects and salbutamol's ones were significant. Thus from $3 \times 10^{-8}$ to $9 \times$ $10^{-6} \mathrm{M}$, salbutamol was more effective than both alkaloids; at $3 \times 10^{-5} \mathrm{M}$, salbutamol was more effective than alkaloid 2 but less effective than alkaloid 1; for the two highest concentrations tested $\left(9 \times 10^{-5}\right.$ and $\left.3 \times 10^{-4} \mathrm{M}\right)$ salbutamol was less effective than both alkaloids (Figure 3).

Salbutamol induced its spasmolytic effect in a different way [from the lowest concentrations its relaxant effect appeared and reached the maximal level at $9 \times 10^{-6}$ $\mathrm{M}$, then decreased for the highest concentrations (Figure 3)], due to a difference in the mechanisms of action. Indeed, the spasmolytic effect of the crude extract from which alkaloids were isolated was not inhibited by $\beta_{2}$-blockers, but was sustained by hyperpolarization [5]; however salbutamol is known to have a $\beta_{2}$-mimetic action [9]. Besides, the increase of salbutamol's spasmolytic effect, for its lowest concentrations, testimonies $\beta_{2}$-receptors sensitation. The decrease of this effect, for its highest concentrations, might be due to $\beta_{2}$-receptors saturation, with desensitation of the subsequent signaling cascade [10]. Nevertheless this probable saturation might not do prejudice to the molecule activity, as salbutamol is well known for its neutralizing action of bronchitis spasm during asthma crisis. Concerning the isolated alkaloids, the steadiness of relaxation going until to a total inhibition of the carbachol-induced pre-contractions is-it in relation with a potent spasmolytic effect? In this connection, it is important to note that authors defend the thesis that herbal in vitro data are questionable in absence of in vivo observations [11]. As a matter of fact, factors like absorption or metabolism of those substances are liable to great differences between their in vitro and in vivo activities [12].

The $\mathrm{E}_{\max }$ value is the percentage of relaxation obtained at the maximal tested concentration. The $\mathrm{EC}_{\mathrm{x}}$ value is defined as the concentration of extract that induces $\mathrm{x} \%$ relaxation. n.d is not determined value.

\section{Conclusion}

This study allowed isolating new structures of alkaloids from plants. Those new components exerted a good ex vivo activity on contracted trachea. Nevertheless, further investigations will be required to completely identify these components, and to confirm their real potency with in vivo bronchodilatation tests.

\section{Acknowledgements}

The authors are grateful to Pr. L. Aké-Assi (Centre National de Floristique d'Abidjan) for botanical identification, to Dr. V. Domergue-Dupont (IFR141, ChâtenayMalabry, France) and her staff for animal care, to Mrs. F. Lefebvre (UMR-S 769, Châtenay-Malabry, France) for technical assistance, to Pr. Attioua (Laboratoire de Chimie Organique Biologique, UFR Sciences des Structures de la Matière et Technologie, Université Félix HouphouëtBoigny, Côte d'Ivoire) and Pr. M. Ouattara (Laboratoire de Chimie Thérapeutique et Biomolécules, UFR Sciences Pharmaceutiques et Biologiques, Université Félix Houphouët-Boigny, Côte d'Ivoire) for their chemical help. Financial supports were provided by the "Centre National de la Recherche Scientifique", the "Institut National de la Santé et de la Recherche Médicale" and the "Université Paris-Sud 11".

\section{REFERENCES}

[1] S. Jayakumari and R. G. Srinivassa, "Effect of Dichro- 
stachys cinerea (Linn.) Root Extract on Ethylene Glycol Induced Urolithiasis in Rats," Natural Product Sciences, Vol. 13, No. 3, 2007, pp. 180-185.

[2] E. J. Adjanohoun, A. M. R. Ahyi and L. Aké-Assi, "Médecine Traditionnelle et Pharmacopée: Contribution aux Etudes Ethnobotaniques et Floristiques au Togo," Agence de Coopération Culturelle et Technique, Paris, 1986.

[3] E. J. Adjanohoun and L. Aké-Assi, "Contribution au Recensement des Plantes Médicinales de Côte d'Ivoire," Centre National de Floristique, Côte d'Ivoire, 1979.

[4] D. Ramanitrahasimbola, D. A. Rakotondramanana, P. Rasoanaivo, A. Randriantsoa, S. Ratsimamanga, G. Palazzino, C. Galeffi and M. Nicoletti, "Bronchodilatator Activity of Phymatodes scolopendria (Burm.) Ching and Its Bioactive Constituents," Journal of Ethnopharmacology, Vol. 102, No. 3, 2005, pp. 400-407. http://dx.doi.org/10.1016/j.jep.2005.06.037

[5] G. Irié-N'guessan, P. Champy, G. Kouakou-Siransy, A. Koffi, B. J. Kablan and V. Leblais, "Tracheal Relaxation of Five Ivorian Anti-Asthmatic Plants: Role of Epithelium and $\mathrm{K}^{+}$Channels in the Effect of the Aqueous-Alcoholic Extract of Dichrostachys cinerea Root Bark," Journal of Ethnopharmacology, Vol. 138, No. 2, 2011, pp. 432-438. http://dx.doi.org/10.1016/j.jep.2011.09.016

[6] B. A. Da Silva, A. P. De Araújo Filho, R. Mukherjee and A. Chiappeta, "Bisnordihydrotoxiferine and Vellosimine from Strychnos divaricans Root: Spasmolytic Properties of Bisnordihydrotoxiferine," Phytotherapy Research, Vol.
7, No. 6, 1993, pp. 419-424. http://dx.doi.org/10.1002/ptr.2650070607

[7] C. C. Shi, J. F. Liao and C. F. Chen, "Spasmolytic Effects of Three Harmala Alkaloids on Guinea-Pig Isolated Trachea," Pharmacology \& Toxicology, Vol. 89, No. 5, 2001, pp. 259-264.

http://dx.doi.org/10.1034/j.1600-0773.2001.d01-157.x

[8] J. Bruneton, "Pharmacognosie: Phytochimie, Plantes Médicinales,’Tec \& Doc Lavoisier, Lavoisier, 2009.

[9] J. Garssen, H. Van Loveren, H. Van der Vliet and F. P. Nijkamp, "An Isometric Method to Study Respiratory Smooth Muscle Responses in Mice," Journal of Pharmacological Methods, Vol. 24, 1990, pp. 209-217. http://dx.doi.org/10.1016/0160-5402(90)90031-F

[10] S. A. Shore and P. E. Moore, "Regulation of $\beta$-Adrenergic responses in Airway Smooth Muscle," Respiratory Physiology \& Neurobiology, Vol. 137, No. 2-3, 2003, pp. 179-195. http://dx.doi.org/10.1016/S1569-9048(03)00146-0

[11] N. R. Farnsworth, O. Akerele, A. S. Bingel, D. D. Soejarto and Z. Guo, "Place des Plantes Médicinales dans la Thérapeutique," Bulletin de l'Oganisation Mondiale de la Santé, Vol. 64, No. 2, 1986, pp. 159-175.

[12] P. J. Houghton, M.-J. Howesb, C. C. Lee and G. Steventon, "Uses and Abuses of in Vitro Tests in Ethnopharmacology: Visualizing an Elephant," Journal of Ethnopharmacology, Vol. 110, No. 3, 2007, pp. 391-400. http://dx.doi.org/10.1016/j.jep.2007.01.032 